\title{
Oral prednisone for chronic active liver disease: dose responses and bioavailability studies ${ }^{1}$
}

\author{
M. URIBE ${ }^{2}$, S. W. SCHALM, W. H. J. SUMMERSKILL ${ }^{3}$, AND V. L. W. GO4 \\ From the Gastroenterology Unit, Mayo Clinic and Mayo Foundation, Rochester, Minnesota, USA
}

SUMMARY Serum concentrations of prednisolone were measured by radioimmunoassay after the administration of prednisone $(10,20$, or $30 \mathrm{mg})$ by mouth to five healthy volunteers, five patients with severe chronic active liver disease (CALD), and five patients with CALD in remission induced by prednisone. Only minor differences were found between the groups and bioavailability was linearly related to the dose of prednisone $(r=0.993)$. After prednisone $(10 \mathrm{mg})$ was given by mouth and by vein to similar groups of volunteers and 11 additional patients with CALD, bioavailability of oral prednisone approximated $100 \%$ of the intravenous dose and no differences were found in the pharmacokinetics of prednisolone. We conclude that prednisone is effectively absorbed and converted to prednisolone in health and CALD and find no pharmacological evidence that either drug would be superior to the other for treating CALD.

Prednisone is frequently prescribed for the treatment of chronic active liver disease (CALD) (Soloway et al., 1972; Murray-Lyon et al., 1973) and must be reduced at the $11 \beta$ keto group for conversion to its active therapeutic derivative, prednisolone (Jenkins and Sampson, 1967). This conversion depend on an $11 \beta$ dehydrogenase, mainly located in the liver (Bush and Mahesh, 1964). We recently showed that impaired liver function resulted in on significant defect in the metabolism to prednisolone of prednisone given by vein (Schalm et al., 1977). However, different methods of administering drugs may alter pharmacokinetics (Gibaldi and Feldman, 1972) and the reduction in systemic availability resulting from hepatic metabolism (Gibaldi et al., 1971; Gram and Overo, 1976) when some compounds are given by mouth is known as the 'first pass' effect. Since prednisone is given by mouth for

'This study was supported in part by Research Grant
AM-6908 from the National Institutes of Health and by a
grant-in-aid from Burroughs Wellcome Company and
Gastrointestinal and Liver Disease Associates (GILDA),
Skokie, Illinois.
'Dr Uribe was supported by a Fogarty International Fellow-
ship FO TW 2303. Present address: Departamento de
Gastroenterologia, Instituto Nacional de la Nutricion,
Mexico 22, D. F. Mexico.
'W. H. J. Summerskill died on 9 March 1977.
'Addruss for reprint requests: Dr V. L. W. Go, Gastro-
enterology Unit, Mayo Clinic, Rochester, Minnesota
55901, USA.

Received for publication 22 September 1978
CALD, concentrations of serum prednisolone will depend on intestinal absorption of prednisone and its conversion to prednisolone in the liver and elsewhere, as well as upon the dose ingested.

Since little information regarding the bioavailability and pharmacokinetic behaviour of prednisolone after oral prednisone is available in health or liver disease, we have investigated these parameters after different oral doses of prednisone and have compared the bioavailability of prednisone after identical oral and intravenous doses.

\section{Methods}

\section{SUBJECTS}

To determine dose responses, five healthy volunteers and 10 patients with CALD were studied (Table 1). Of these, five were untreated and fulfilled functional and histological criteria for severe CALD (Soloway et al., 1972), and five patients were asymptomatic, having responded to treatment with prednisone by resolution (Soloway et al., 1972) of earlier histological or functional indicators of disease activity.

For bioavailability studies, five healthy volunteers and 11 additional patients (Table 2) with CALD also participated. Of these, five had severe, untreated CALD and six had responded to treatment with prednisone. All individuals were admitted to a metabolic unit after medications had been discontinued for 24 hours. None had been taking drugs believed to induce microsomal enzymes. Seven 
Table 1 Findings in individuals participating in dose response studies

\begin{tabular}{|c|c|c|c|}
\hline Group & Health & $\begin{array}{l}C A L D \\
\text { remission }\end{array}$ & $\begin{array}{l}\text { Severe } \\
C A L D\end{array}$ \\
\hline Number of individuals & 5 & 5 & 5 \\
\hline Sex, M/F & $2 / 3$ & $1 / 4$ & $1 / 4$ \\
\hline Age, yr (mean) & 38 & 34 & 40 \\
\hline Weight, kg (mean) & 72 & 75 & 60 \\
\hline $\begin{array}{l}\text { Serum bilirubin, } \mu \mathrm{mol} / 1 \\
\text { (mean) } \mathrm{N}:<21\end{array}$ & 10 & 17 & 43 \\
\hline $\begin{array}{l}\text { Serum GOT, IU/1 (mean) } \\
\mathrm{N}:<24\end{array}$ & 18 & 26 & 164 \\
\hline $\begin{array}{l}\text { Serum albumin, } \mathrm{g} / \mathrm{l} \text { (mean) } \\
\mathrm{N}: 35-47\end{array}$ & 43 & 42 & 35 \\
\hline $\begin{array}{l}\text { Serum gamma globulin } \mathrm{g} / \mathrm{l} \\
\text { (mean) } \mathrm{N}: 8-16\end{array}$ & 10 & 14 & 20 \\
\hline Cirrhosis* & - & 2 & 1 \\
\hline
\end{tabular}

* No biopsies were available from healthy volunteers.

Table 2 Findings in individuals participating in bioavailability studies

\begin{tabular}{llll}
\hline Group & Health & $\begin{array}{c}\text { CALD } \\
\text { remission }\end{array}$ & $\begin{array}{c}\text { Severe } \\
\text { CALD }\end{array}$ \\
\hline Number of individuals & 5 & 6 & 5 \\
Sex, M/F & $3 / 2$ & $3 / 3$ & $2 / 3$ \\
Age, yr (mean) & 36 & 38 & 51 \\
Weight, kg (mean) & 76 & 77 & 73 \\
$\begin{array}{l}\text { Serum bilirubin, } \mu \text { mol/1 } \\
\text { (mean) N: <21 }\end{array}$ & 10 & 17 & 96 \\
$\begin{array}{l}\text { Serum GOT, IU/1 (mean) } \\
\quad \text { N: <24 }\end{array}$ & 20 & 46 & 574 \\
$\begin{array}{l}\text { Serum albumin, g/l (mean) } \\
\quad \text { N: 35-47 }\end{array}$ & 42 & 38 & 36 \\
$\begin{array}{l}\text { Serum gamma globulin g/1 } \\
\quad \text { (mean) N: 8-16 }\end{array}$ & 11 & 14 & 24 \\
$\begin{array}{l}\text { Cirrhosis* } \\
\quad\end{array}$ & - & 4 & 2 \\
\hline
\end{tabular}

*No biopsies were available from healthy volunteers.

patients were taking azathioprine $50 \mathrm{mg} /$ day 48 hours before the study.

For dose response studies, a 19 gauge needle was placed in an antecubital vein and was kept patent throughout the study by irrigation with saline. After a baseline blood sample, patients received (on randomised days) oral doses of 10 or $30 \mathrm{mg}$ prednisone (two or six $5 \mathrm{mg}$ tablets of Meticorten) with $180 \mathrm{ml}$ water. Volunteers were also studied on a third day, receiving $20 \mathrm{mg}$ prednisone (four tablets, $5 \mathrm{mg}$ each) in $180 \mathrm{ml}$ water. Blood samples were drawn at 0.5 , one hour, and then hourly for a total of eight hours. Apart from lying down for 30 minutes before samples were taken, patients were up and about. Meals were given at two, four, and eight hours after the study started and had no significant effect on serum prednisolone concentrations (Uribe et al., 1976b).

For bioavailability studies, the procedure was similar to that outlined, except that subjects received $10 \mathrm{mg}$ prednisone on different days, given either by mouth (two $5 \mathrm{mg}$ tablets Meticorten) with $180 \mathrm{ml}$ water or dissolved in $3.3 \mathrm{ml} 50 \%$ ethanol and given by vein over a five-minute period during a rapid simultaneous infusion of saline. After prednisone was given by vein, additional blood samples were obtained at 0.1 and 0.3 hours.

Samples of blood were centrifuged, the serum then being separated and kept frozen at $-70^{\circ} \mathrm{C}$ until further analysis. Prednisolone was determined by a specific radioimmunoassay which reliably detected prednisolone at concentrations $\leq 40 \mathrm{ng} / \mathrm{ml}$ (coefficient of variation $<8.5 \%$ ) and is described elsewhere (Schalm et al., 1976).

Measurements of pharmacokinetic parameters of prednisolone included peak time, peak concentrations and elimination half life (Koch-Weser, 1974). This last value was calculated by linear regression from the logarithm of serum concentrations, taking at least four points beyond the peak value. The integrated area under the serum concentration curve (AUC) from zero to infinity was calculated by the numerical integration using the trapezoidal rule on a PDP 8/e (Digital Equipment Company, Maynard, MA). The general formula used was (Shull et al., 1976):

$$
\begin{aligned}
\text { AUC } & =1 / 2\left(Y_{0}+Y_{i}\right)\left(X_{1}-X_{0}\right) \\
& +1 / 2\left(Y_{1}+Y_{2}\right)\left(X_{2}-X_{1}\right)+--- \\
& +1 / 2\left(Y_{(n-1)}+Y_{n}\right)\left(X_{n}-X_{(n-1)}\right)
\end{aligned}
$$

thus, the amount entering the systemic circulation is equal to the integrated concentration over time $(\Sigma \mathrm{C} \mathrm{dt})$.

Bioavailability of oral doses was determined (Raaflaub and Dubach, 1975) as follows:

$\begin{aligned} & \text { oral prednisone } \\ & \text { bioavailability }\end{aligned}=\frac{\text { oral prednisolone AUC }}{\text { IV prednisolone AUC }} \times 100$

and volume of distribution was calculated as follows:

$\mathrm{Vd}=\frac{\text { dose T } 1 / 2}{0.693 \text { AUC }}$ (Shull et al., 1976). Pharma-

cokinetic values were compared for statistical significance by Student's $t$ test.

\section{Results}

DOSE RESPONSE STUDIES

Profiles for serum concentrations of prednisolone in volunteers and patients with CALD (Fig. 1) show peak levels of prednisolone at approximately 200 $\mathrm{ng} / \mathrm{ml}, 300 \mathrm{ng} / \mathrm{ml}$, and $500 \mathrm{ng} / \mathrm{ml}$ after oral doses of 10,20 , and $30 \mathrm{mg}$ prednisone respectively. No striking differences occurred between patients and volunteers. Peak heights were also similar (Table 3). Peak appearance of prednisolone often occurred sooner in patients with CALD previously treated with prednisone than those with untreated severe CALD or healthy individuals. Pharmacokinetic measure- 
Oral prednisone for chronic active liver disease: dose responses and bioavailability studies

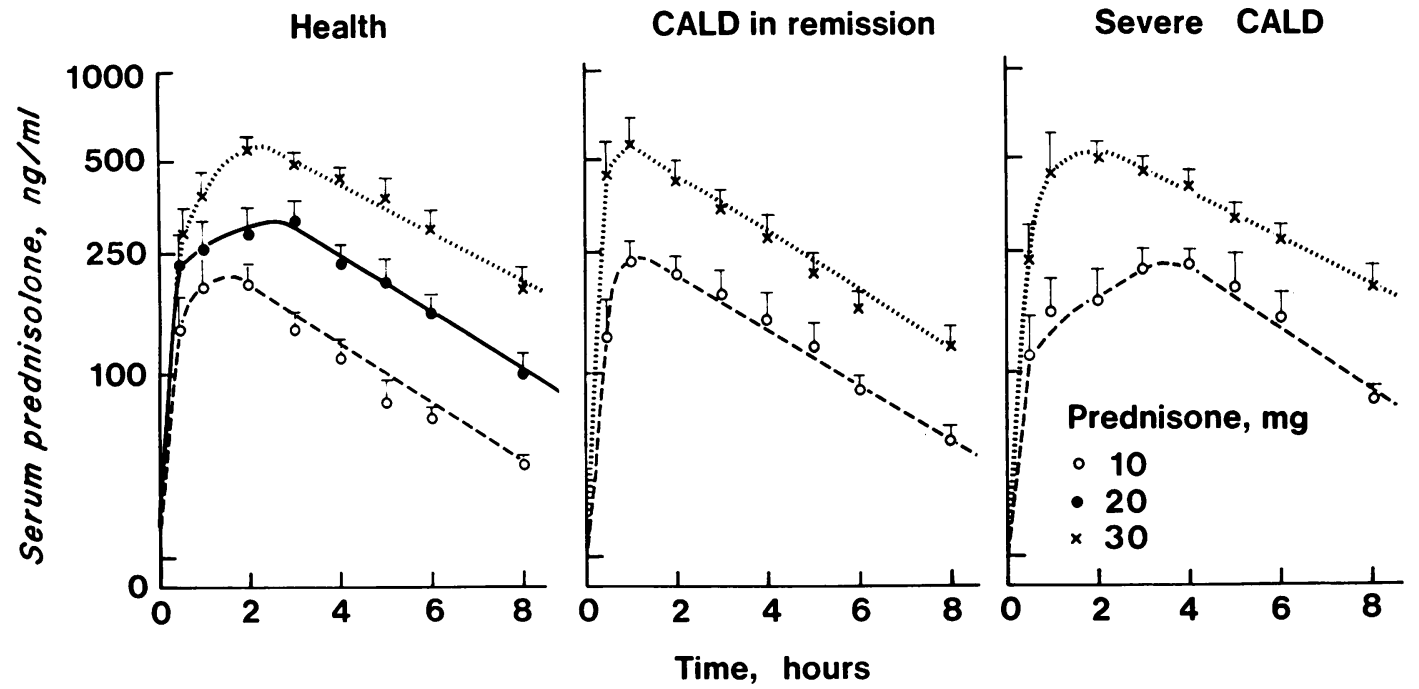

Fig. 1 Serum prednisolone profiles after 10,20, or $30 \mathrm{mg}$ prednisone was given by mouth to healthy volunteers $(N=5)$, patients with treated $C A L D$ in remission $(N=5)$ and untreated patients with severe $C A L D(N=5)$. Each point represents mean $\pm S E$.

Table 3 Dose response studies: pharmacokinetic parameters (mean $\pm S E$ ) of prednisolone

\begin{tabular}{|c|c|c|c|c|}
\hline Parameter & $\begin{array}{l}\text { Oral dose } \\
\text { administered }\end{array}$ & Health & $C A L D$ remission & Severe $C A L D$ \\
\hline $\begin{array}{l}\text { Peak height } \\
\text { (ng/ml) }\end{array}$ & $\begin{array}{l}10 \\
20 \\
30\end{array}$ & $\begin{array}{l}244 \pm 38 \\
386 \pm 51 \\
596 \pm 43\end{array}$ & $\begin{array}{l}269 \pm 23 \\
586 \pm 51\end{array}$ & $\begin{array}{l}265 \pm 26 \\
563 \pm 69\end{array}$ \\
\hline $\begin{array}{l}\text { Peak time } \\
\text { (h) }\end{array}$ & $\begin{array}{l}10 \\
20 \\
30\end{array}$ & $\begin{array}{ll}1 \cdot 6 \pm & 0 \cdot 2 \\
2 \cdot 4 \pm & 0.4 \\
2 \cdot 6 \pm & 0.4\end{array}$ & $\begin{array}{l}1.6 \pm 0.4 \\
0.9 \pm 0.1 *\end{array}$ & $\begin{array}{l}3.2 \pm 0.9 \\
2.2 \pm 0.4\end{array}$ \\
\hline $\begin{array}{l}\text { Half life } \\
\text { (h) }\end{array}$ & $\begin{array}{l}10 \\
20 \\
30\end{array}$ & $\begin{array}{ll}3.0 \pm & 0.2 \\
3.5 \pm & 0.4 \\
3.7 \pm & 0.3\end{array}$ & $\begin{array}{l}2.5 \pm 0.2 \\
2.6 \pm 0.1^{*}\end{array}$ & $\begin{array}{l}3.8 \pm 0.9 \\
3.8 \pm 0.1\end{array}$ \\
\hline $\begin{array}{l}\text { Apparent volume } \\
\text { of distributions } \\
\text { (1) }\end{array}$ & $\begin{array}{l}10 \\
20 \\
30\end{array}$ & $\begin{array}{r}50 \pm \\
103 \pm \\
176 \pm \\
\pm\end{array}$ & $\begin{array}{r}45 \pm 7 \\
146 \pm 18\end{array}$ & $\begin{array}{r}76 \pm 21 \\
219 \pm 33\end{array}$ \\
\hline $\begin{array}{l}\text { Area under } \\
\text { serum } \\
\text { concentrations } \\
0-00 \\
\text { (ng/ml/h) }\end{array}$ & $\begin{array}{l}10 \\
20 \\
30\end{array}$ & $\begin{array}{l}1016 \pm 145 \\
1991 \pm 302 \\
3456 \pm 388\end{array}$ & $\begin{array}{l}1197 \pm 163 \\
3154 \pm 285\end{array}$ & $\begin{array}{l}1411 \pm 235 \\
4171 \pm 322\end{array}$ \\
\hline
\end{tabular}

$* \mathrm{P}<0.005$.

ments (Table 3) showed no differences in peak height. Serum half life was shorter in patients receiving treatment with prednisone than in others and a direct relationship $(r=0.993 ; \mathrm{P}<0.001)$ was shown between dose administered (mg) and the integrated AUC.

BIOAVAILABILITY OF PREDNISOLONE AFTER ORAL OR INTRAVENOUS ADMINISTRATION OF PREDNISONE (Fig. 2)

Serum prednisolone rose immediately after the intravenous bolus was given and peak values of about $300 \mathrm{ng} / \mathrm{ml}$ occurred after 30 minutes, the findings being similar in all groups. Very similar profiles of serum prednisolone concentrations were found after prednisone was given by mouth, apart from a slight delay in peak values in untreated patients with severe CALD. Other pharmacokinetic parameters showed no significant differences between modes of administration (Table 4) and, in particular, bioavailability of oral prednisone approximated $100 \%$ of the values after intravenous dosage, thus suggesting complete absorption of prednisone from the gastrointestinal tract. 
Health

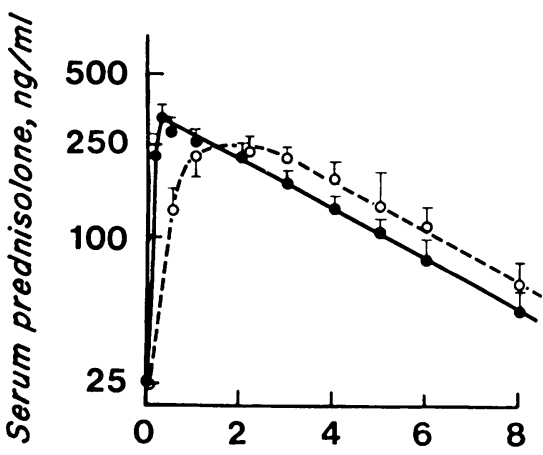

CALD in remission

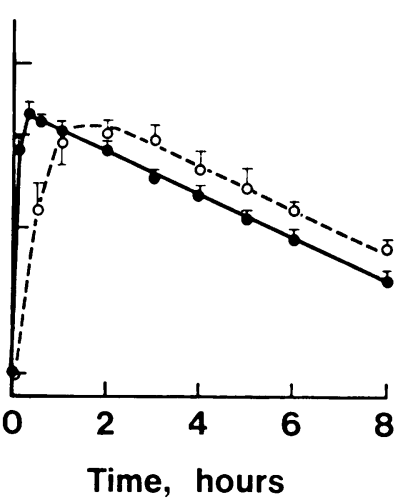

Severe CALD

Prednisone, 10 mg

- by vein

- by mouth

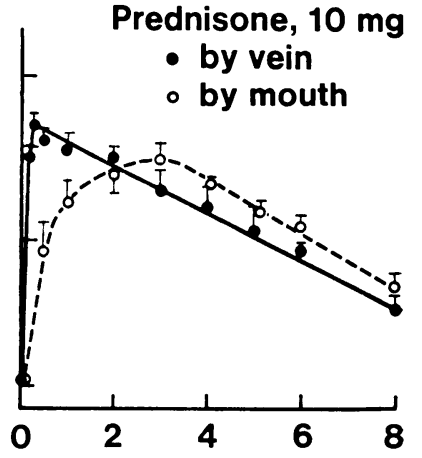

Fig. 2 Appearance of prednisolone in serum after $10 \mathrm{mg}$ prednisone was given by vein or by mouth to healthy volunteers $(N=5)$, patients with treated CALD in remission $(N=6)$ or untreated patients with severe CALD $(N=5)$. Each point represents mean $\pm S E$.

Table 4 Bioavailability studies: pharmacokinetic parameters (mean $\pm S E$ ) of prednisolone

\begin{tabular}{|c|c|c|c|c|}
\hline Parameter & $\begin{array}{l}\text { Route of } \\
\text { administration }\end{array}$ & Health & $C A L D$ remission & Severe CALD \\
\hline $\begin{array}{l}\text { Peak height } \\
\text { (ng/ml) }\end{array}$ & $\begin{array}{l}\text { Oral } \\
\text { IV }\end{array}$ & $\begin{array}{l}319 \pm 31 \\
305 \pm 34\end{array}$ & $\begin{array}{l}264 \pm 25 \\
318 \pm 31\end{array}$ & $\begin{array}{l}253 \pm 33 \\
306 \pm 23\end{array}$ \\
\hline $\begin{array}{l}\text { Peak time } \\
\text { (h) }\end{array}$ & $\begin{array}{l}\text { Oral } \\
\text { IV }\end{array}$ & $\begin{array}{ll}1.7 & \pm \\
0.34 & 0.47 \\
& 0.04\end{array}$ & $\begin{array}{ll}2.1 & \pm 0.4 \\
0.3 \pm & 0\end{array}$ & $\begin{array}{l}2.6 \pm 0.5 \\
0.34 \pm 0.04\end{array}$ \\
\hline $\begin{array}{l}\text { Half life } \\
\text { (h) }\end{array}$ & $\begin{array}{l}\text { Oral } \\
\text { IV }\end{array}$ & $\begin{array}{lll}3.4 & \pm & 0.4 \\
3.3 & \pm & 0.2\end{array}$ & $\begin{array}{l}3.0 \pm 0.25 \\
2.9 \pm \quad 0.21\end{array}$ & $\begin{array}{l}2.9 \pm 0.4 \\
3.3 \pm 0.1\end{array}$ \\
\hline $\begin{array}{l}\text { AUC } \\
\text { (ng/ml/h) } \\
0-00\end{array}$ & $\begin{array}{l}\text { Oral } \\
\text { IV }\end{array}$ & $\begin{array}{l}1265 \pm 102 \\
1252 \pm 108\end{array}$ & $\begin{array}{l}1241 \pm 210 \\
1300 \pm 191\end{array}$ & $\begin{array}{l}1235 \pm 91 \\
1283 \pm 76\end{array}$ \\
\hline $\begin{array}{l}\text { Oral } \\
\text { bioavailability } \\
(\%)\end{array}$ & & $101 \pm 19$ & $98 \pm 24$ & $94 \pm 7$ \\
\hline
\end{tabular}

\section{Discussion}

Our findings show that when prednisone is given by mouth rapid absorption from the gastrointestinal tract and efficient conversion to prednisolone occur. The liver exerts no appreciable 'first pass' effect, since bioavailability of prednisone is similar whether prednisone is given by mouth or vein. These conclusions were shown to apply to customary doses of prednisone $(10$ to $30 \mathrm{mg}$ ) and a linear relationship was demonstrated between the dose administered and the amount of bioavailable prednisolone which resulted.

As in our earlier studies, which used only intravenous administration of prednisone, there were few and small differences between pharmacokinetic parameters of prednisolone among healthy individuals, patients with liver disease in remission, and patients with severe chronic active liver disease (Schalm et al., 1977). The delay in peak prednisolone concentrations in the last group is unlikely to have therapeutic significance and may be produced by slower conversion of prednisone to prednisolone by the liver. By contrast, patients whose chronic active liver disease had entered remission as a result of treatment with prednisone, had a shorter prednisolone half life than other groups. This was noted earlier by us when prednisone was given intravenously (Schalm et al., 1977) and we considered that it could most reasonably be attributed to induction of hepatic microsomal enzymes (Kozower et al., 1974). Preservation of conversion of prednisone to prednisolone despite severely impaired hepatic function implies either abundant $11 \beta$ dehydrogenase activity in other tissues or maintenance of hepatic hydroxylase activity despite considerable deterioration in conventional clinical and biochemical criteria of hepatic function. Both mechanisms have been described in other circumstances (Bush, 1969; Remmer, 1970) 
and may contribute.

For practical purposes our results show that prednisone and prednisolone are likely to be equally effective at the same dose for the treatment of chronic active liver disease. Our more recent studies (Uribe et al.,1976a) support this conclusion by demonstrating considerable interconversion between the two compounds regardless of what is administered. In the context of these various findings, it is probably pertinent that prednisone retails (in Rochester, MN) for considerably less than half the price of equivalent doses of prednisolone.

We greatly appreciate the continued collaboration of our patients and their home physicians and gratefully acknowledge the assistance of the staff of the Clinical Study Unit, of Audrey Wolf, R.N., and of Mr Dan Kluge, who performed the radioimmunoassays.

\section{References}

Bush, I. E. (1969). 11 $\beta$-hydroxysteroid dehydrogenase: contrast between studies in vivo and studies in vitro. Advances in the Biosciences, 3, 23-40.

Bush, I. E., and Mahesh, V. B. (1964). Metabolism of 11oxygenated steroids. 3. Some 1-dehydro and 9-a-fluoro steroids. Biochemical Journal, 93, 236-255.

Gibaldi, M., Boyes, R. N., and Feldman, S. (1971). Influence of first pass effect on availability of drugs on oral administration. Journal of Pharmaceutical Sciences, 60, 1338-1340.

Gibaldi, M., and Feldman, S, (1972). Route of administration and drug metabolism. European Journal of Pharmacology, 19, 323-329.

Gram, L. F., and Overo, K. F. (1976). First-pass metabolism of nortriptyline in man. Clinical Pharmacology and Therapeutics, 18, 305-314.

Jenkins, J. S., and Sampson, P. A. (1967). Conversion of cortisone to cortisol and prednisone to prednisolone. British Medical Journal, 2, 205-207.

Koch-Weser, J. (1974). Bioavailability of drugs. New England Journal of Medicine, 291, 233-237.

Kozower, M., Veatch, L., and Kaplan, M. M. (1974). Decreased clearance of prednisolone, a factor in the development of corticosteroid side effects. Journal of Clinical Endocrinology and Metabolism, 38, 407-412.

Murray-Lyon, I. M., Stern, R. B., and Williams, R. (1973). Controlled trial of prednisone and azathioprine in active chronic hepatitis. Lancet, 1, 735-737.

Raaflaub, J., and Dubach, U. C. (1975). On the pharmacokinetics of phenacetin in man. European Journal of Clinical Pharmacology, 8, 261-265.

Remmer, H. (1970). The role of the liver in drug metabolism. American Journal of Medicine, 49, 617-629.

Schalm, S. W., Summerskill, W. H. J., and Go, V. L. W. (1976). Development of radioimmunoassays for prednisone and prednisolone: application to studies of hepatic metabolism of prednisone. Mayo Clinic Proceedings, 51, 761766.

Schalm, S. W., Summerskill, W. H. J., and Go, V. L. W. (1977). Prednisone for chronic active liver disease: pharmacokinetics, including conversion to prednisolone. Gastroenterology, 72, 910-913.

Shull, H. J., Jr., Wilkinson, G. R., Johnson, R., and Schenker, S. (1976). Normal disposition of oxazepam in acute viral hepatitis and cirrhosis. Annals of Internal Medicine, 84, 420-425.

Soloway, R. D., Summerskill, W. H. J., Baggenstoss, A. H., Geall, M. G., Gitnick, G. L., Elveback, L. R., and Schoenfield, L. J, (1972). Clinical, biochemical, and histological remission of severe chronic active liver disease: a controlled study of treatments and early prognosis. Gastroenterology, 63, 820-833.

Uribe, M., Go, V. L. W., and Summerskill, W. H. J. (1976a). Kinetics and inter-conversion of prednisone and prednisolone compared in chronic active liver disease (CALD) after oral doses. (Abstract.) Gastroenterology, 71, 932.

Uribe, M., Schalm, S. W., Summerskill, W. H. J., and Go, V. L. W. (1976b). Effect of liquid diet on serum protein binding and prednisolone concentrations after oral prednisone. Gastroenterology, 71, 362-364. 